\title{
A new molecular risk pathway for postpartum mood disorders: clues from steroid sulfatase-deficient individuals
}

\author{
Harish Thippeswamy ${ }^{1}$ (D) William Davies ${ }^{2,3,4}$ [D \\ Received: 22 July 2020 / Accepted: 13 November 2020 / Published online: 20 November 2020 \\ (C) The Author(s) 2020
}

\begin{abstract}
Postpartum mood disorders develop shortly after childbirth in a significant proportion of women. These conditions are associated with a range of symptoms including abnormally high or low mood, irritability, cognitive disorganisation, disrupted sleep, hallucinations/delusions, and occasionally suicidal or infanticidal ideation; if not treated promptly, they can substantially impact upon the mother's health, mother-infant bonding, and family dynamics. The biological precipitants of such disorders remain unclear, although large changes in maternal immune and hormonal physiology following childbirth are likely to play a role. Pharmacological therapies for postpartum mood disorders can be effective, but may be associated with side effects, concerns relating to breastfeeding, and teratogenicity risks when used prophylactically. Furthermore, most of the drugs that are used to treat postpartum mood disorders are the same ones that are used to treat mood episodes during non-postpartum periods. A better understanding of the biological factors predisposing to postpartum mood disorders would allow for rational drug development, and the identification of predictive biomarkers to ensure that 'at risk' mothers receive earlier and more effective clinical management. We describe new findings relating to the role of the enzyme steroid sulfatase in maternal postpartum behavioural processes, and discuss how these point to a novel molecular risk pathway underlying postpartum mood disorders. Specifically, we suggest that aberrant steroid hormone-dependent regulation of neuronal calcium influx via extracellular matrix proteins and membrane receptors involved in responding to the cell's microenvironment might be important. Testing of this hypothesis might identify novel therapeutic targets and predictive biomarkers.
\end{abstract}

Keywords Calcium signalling · Cellular Communication Network Factor · Oestrogen · Phosphodiesterase 10A · Psychosis · Transient Receptor Potential Cation Channel Subfamily M Member 3 (TRPM3)

\section{A brief introduction to postpartum mood disorders}

Following childbirth, women can present with a number of mood conditions, ranging in prevalence and severity. The

William Davies

daviesw4@cardiff.ac.uk

1 Department of Psychiatry, National Institute of Mental Health and Neuro Sciences (NIMHANS), Bangalore, India

2 Centre for Neuropsychiatric Genetics and Genomics and Division of Psychological Medicine and Clinical Neurosciences, School of Medicine, Cardiff University, Cardiff, UK

3 School of Psychology, Cardiff University, Tower Building, 70, Park Place, Cardiff CF10 3AT, UK

4 Neuroscience and Mental Health Research Institute, Cardiff University, Cardiff, UK 'baby blues', which affects $\sim 40 \%$ of new mothers, is associated with comparatively mild depressive symptoms which typically resolve spontaneously within a relatively short timeframe (Rezaie-Keikhaie et al. 2020). The symptoms of postpartum depression (PPD) are similar to, but more severe and more prolonged than, those associated with the baby blues; they can onset up to one year post-childbirth and often require medical treatment (Meltzer-Brody et al. 2018b). The point prevalence of postpartum depression has been estimated as being between 13 and $20 \%$ within the general population, and up to $35 \%$ of individuals with a previous psychiatric history; notable psychosocial risk factors include young age and lack of social support, a personal or family history of depression, and exposure to adverse early-life adverse events (Meltzer-Brody et al. 2018b). Perinatal anxiety, often associated with abnormal concerns about the welfare of the newborn baby, is thought to affect $\sim 20 \%$ of all mothers (Fawcett et al. 2019). Furthermore, childbirth may precipitate a recurrence of 
bipolar illness, especially amongst women with bipolar disorder and a past history of perinatal depression or affective psychosis (Di Florio et al. 2018). Postpartum psychosis (PP) is the rarest and arguably most severe of the postpartum mood disorders, and is thought to affect $0.89-2.6$ of every 1000 mothers (VanderKruik et al. 2017). PP is associated with significant mood symptoms (including depression and mania), with cognitive disorganisation and confusion, with hallucinations and delusions (often baby-orientated), and with substantial changes to sleep patterns (Bergink et al. 2016); a prior diagnosis of bipolar disorder is a strong risk factor for PP and women who experience mania following sleep loss may be at particular risk (Lewis et al. 2018). However, nearly twothirds of women who experience PP have no prior psychiatric history (Blackmore et al. 2013). Postpartum mood disorders are frequently comorbid with other medical conditions including thyroid disorders (Bergink et al. 2011; Guintivano et al. 2018; Minaldi et al. 2020) and pre-eclampsia (Bergink et al. 2015; Caropreso et al. 2019).

Despite preventative strategies being employed for women at known risk of postpartum mood disorders, some new mothers will nevertheless be affected. Treatments for such disorders are often reasonably effective if administered shortly after symptom onset. These include pharmacotherapy (antidepressant, mood-stabilising, anxiolytic, sedative, and antipsychotic drugs administered alone or in some combination), electroconvulsive therapy, psychological therapies, and family/social support; in rare cases where the disorder has an underlying autoimmune basis, interventions targeting the immune system may be efficacious (Meltzer-Brody et al. 2018b; Reddy et al. 2018). However, these approaches are not universally effective and can result in unpleasant side effects, and caution is warranted when taking some medications prophylactically or whilst breastfeeding given the risk of teratogenicity to the foetus in utero, or of consumption by the feeding infant, respectively (Lusskin et al. 2018; Poels et al. 2018).

A significant biological contribution to postpartum mood disorder risk is likely: these conditions are closely temporally linked to the maternal physiological perturbations following childbirth, they are associated with a similar range of symptoms and prevalence across differing cultures and societies, and they tend to run in families with individuals affected by one episode at risk for subsequent births. Much work investigating the biological basis of postpartum mood disorders has focussed upon physiological systems which are in flux during pregnancy (particularly late pregnancy) and into the puerperium. After the steroidogenic placenta is expelled and as gonadal production of steroid hormones stabilises following parturition, levels of oestrogens, progesterone, and the progesterone metabolite allopregnanolone plummet acutely; these hormones typically act on the limbic regions of the brain involved in emotional and cognitive processing, motivation, and arousal, modulating neurotransmitter (notably gamma- aminobutyric acid receptor type $\mathrm{A}\left(\mathrm{GABA}_{\mathrm{A}}\right)$ receptor) function (Meltzer-Brody et al. 2018b). Abnormal sensitivity to this steroid hormone depletion, perhaps mediated in part via GABAergic maladaptation, has been proposed to account for postpartum mood disorder risk (Meltzer-Brody et al. 2018b). Recent studies linking allopregnanolone levels to depressive-anxiety symptoms, and showing beneficial effects of allopregnanolone administration in women with postpartum depression, emphasise the potential importance of this particular compound (Deligiannidis et al. 2016; MeltzerBrody et al. 2018a; Paul et al. 2020). Links between postpartum mental health risk and levels/activity of other reproductive, stress, and thyroid hormones have also been proposed, but these appear less consistent and are of more uncertain impact (Meltzer-Brody et al. 2018b). Immune perturbation in the postpartum period, specifically an imbalance between pro- and anti-inflammatory factors, has also been suggested as a candidate risk mechanism (Bergink et al. 2013; Kumar et al. 2017; Meltzer-Brody et al. 2018b; Dazzan et al. 2018); this imbalance may be related to changes in steroid hormone levels (Bouman et al. 2005) or may be aetiologically distinct. In a diathesis model, the underlying sensitivity to acute postpartum hormonal and immune changes may be partially explained by (epi)genetic factors. To date, (epi)genetic studies in these conditions have focussed upon candidate genes, or have been underpowered to robustly detect risk variants with meaningful effects; however, animal model and follow-up clinical work has indicated promising hormone-sensitive epigenetic signatures around the HP1BP3 and TTC9B loci that may be associated with postpartum depression (Payne et al. 2020). With the establishment of large consortia and better-powered genome-wide screens, over the next few years, such variants may be identified.

Animal models in which experimental variables can be systematically altered, and in which access to relevant brain tissue is not a concern, may be informative for understanding the biology of postpartum mood conditions; such models include selective breeding models, behavioural models where pregnant mothers are repeatedly exposed to stress throughout pregnancy and the postpartum period, or pharmacological models involving the administration/withdrawal of stress and steroid hormones (Perani and Slattery 2014); however, mammalian models such as rodents differ significantly from humans in terms of their reproductive function and the extent to which findings can be generalised across species is unclear (Martin 2007).

Clarifying the biological factors underlying postpartum mood disorder risk through parallel clinical and animal model studies will increase the likelihood of identifying targets for more effective medications with fewer and/or less severe side effects, of understanding variability in individual treatment response to existing drugs, and of characterising biomarkers with possible predictive potential. Below, we argue that the 
enzyme steroid sulfatase may be a mediator of maternal behaviour, and that the downstream pathways it influences may be disrupted in idiopathic postpartum mood disorders.

\section{Steroid sulfatase: Its function and expression pattern}

Steroid sulfatase (STS) is an enzyme encoded by the X-linked STS gene located at Xp22.31 (Reed et al. 2005). It appears to be the sole mediator of steroid desulfation in mammals, cleaving sulfate groups from a variety of relatively inert, watersoluble compounds to convert them to more active, less soluble moieties which can act as precursors for a variety of oestrogens and androgens (Mueller et al. 2015).

In the developing human foetus, STS is expressed in numerous regions of the brain (most highly in the hypothalamus and the anterior lobe of the pituitary gland, thalamus, cortex, cerebellar neuroepithelium, and basal ganglia), as well as in the thyroid gland (Stergiakouli et al. 2011) and the placenta (Geyer et al. 2017); in adult tissues, STS continues to be expressed in the brain (most highly in the frontal cortex) and in the thyroid gland (GTEx Portal 2020). There is some evidence that in mammals, brain and peripheral STS protein levels/activity increase towards late pregnancy and into the postpartum period (Davies 2018). In the brain, sulfated and free steroids have partially dissociable activities at membrane proteins including $\mathrm{GABA}_{\mathrm{A}}$ and $N$-methyl-D-aspartate (NMDA) receptors which act as ligand-gated chloride and sodium/calcium ion channels respectively (Davies 2012); levels of these compounds also correlate with markers of immune function during pregnancy and into the postpartum period (Tagawa et al. 2004a; Tagawa et al. 2004b).

As STS is expressed in relevant tissues, as its expression/ activity changes with pregnancy and into the postpartum period, and as it modulates hormonal/neurochemical systems and immune processes associated with mood, its deficiency represents a plausible mechanism to partially explain postpartum mood disorders (Davies 2012; Davies 2018).

\section{Mood abnormalities in steroid sulfatase-deficient individuals}

\section{Human data}

Approximately 1 in 750 females from the general population is heterozygous for genetic variants in which the STS gene is partially or completely deleted (Trent and Davies 2013; Brcic et al. 2020); as the STS gene escapes X-inactivation, these individuals have reduced enzyme activity (Lykkesfeldt et al. 1984). Comprehensive phenotyping of this group has indicated no increased risk of most physical medical conditions, but an increased risk of developmental disorders and associated traits (Cavenagh et al. 2019; Brcic et al. 2020). Outside of the postpartum period, compared to females from the general population, these women also present with elevated levels of mood symptoms including irritability, psychological distress, manic symptoms, and tiredness or low energy, as well as differences with respect to sleeping patterns and weight change (Cavenagh et al. 2019; Brcic et al. 2020). These mood symptoms may be related to a smaller volume of some striatal regions in the brain (Brcic et al. 2020). A study of two female cases with STS deficiency has suggested a possible link to psychotic disorder (paranoid schizophrenia) (Milunsky et al. 1999), although traits related to psychosis were not enriched in larger samples of STS-deficient women (Cavenagh et al. 2019; Brcic et al. 2020).

With respect to the postpartum period, STS-deficient females are more likely than control females to be diagnosed with a mental health condition, notably mild-moderate depression; limited power prevented meaningful analysis of postpartum psychosis rates between groups (Cavenagh et al. 2019). Importantly, the excess of depression-related diagnoses in the STS-deficient group does not seem to be due to increased adverse experiences; moreover, postpartum and nonpostpartum depressive traits appear to be dissociable to some extent, suggesting the possibility that STS deficiency in the postpartum period might exacerbate pre-existing non-postpartum psychiatric symptoms (Cavenagh et al. 2019).

\section{Animal model data}

Work in male rodents has shown that deletion of the Sts gene, or acute inhibition of the STS enzyme, is associated with numerous behavioural phenotypes including inattention, anxiety-related behaviours, aggression, perseveration, learning and enhanced memory, and behavioural inhibition (Johnson et al. 2000; Nicolas et al. 2001; Davies et al. 2009; Trent et al. 2012b; Babalola et al. 2012; Trent et al. 2013; Davies et al. 2014); these phenotypes may be partially related to serotonergic and cholinergic differences in the hippocampus (Trent et al. 2012a; Trent et al. 2013; Yue et al. 2016). In both rodents and humans, the quality of maternal behaviours is related to maternal executive function (notably offspringrelated learning and memory processes, attention to relevant care cues, behavioural flexibility, and impulse regulation) mediated by cholinergic, GABAergic, and serotonergic processes (Davies 2018). Thus, steroid sulfatase appears to influence the mood, behavioural, cognitive, and neurochemical processes associated with effective maternal behaviour.

In female mammals, the idea that STS is associated with postpartum behavioural changes is supported by genetic evidence from a porcine model of relevance to postpartum psychosis where STS lies under a candidate quantitative trait locus (Quilter et al. 2007). Additional support comes from a study in 
which STS was acutely inhibited in new mouse mothers (Humby et al. 2016); these mice showed alterations in various emotional behaviours, i.e. a reduced startle response to an intense acoustic stimulus and altered exploration of an aversive environment. The behavioural abnormalities could be partially alleviated by the administration of the atypical antipsychotic ziprasidone.

Together, the human and animal model data discussed above imply a role for STS in both non-postpartum and postpartum mood symptoms, and suggest that identification of the cellular and molecular pathways disrupted by STS deficiency might indicate novel convergent pathways underlying postpartum mood disorders more generally. Of course, it must be emphasised that risk for these disorders is complex and multifactorial, and that STS-related risk pathways, should they exist, will act in combination with multiple other predisposing and protective factors.

\section{Molecular mechanisms associated with postpartum symptoms in steroid sulfatase-deficient females}

\section{Perturbed mechanosensory and olfactory function}

Whole-brain gene expression analysis in mice in which the STS enzyme was acutely inhibited in the postpartum period identified two genes (Cyp2gl and Stoml3) which were significantly and robustly upregulated ( $>1.5$-fold change, $p<0.05$ ) (Humby and Davies 2019); these genes both have human orthologues (CYP2G1P at 19q13.2 and STOML3 at 13q13.3). CYP2G1P encodes a P450 enzyme important in the olfactory system, although functional alleles in humans are rare (Sheng et al. 2000); functional alleles are expressed throughout the adult brain at low levels (GTEx Portal 2020). STOML3, a gene expressed at low levels in the adult human hypothalamus, hippocampus, and basal ganglia (GTEx Portal 2020), encodes a protein important in the gating of Piezo mechanically gated and acid-sensing cation channels and mechanosensory processes through its interactions with membrane cholesterol (Qi et al. 2015; Wetzel et al. 2017); acidsensing ion channels play a key role in fear and anxiety-related psychiatric disorders (Zha 2013). Although CYP2G1P and STOML3 have not been directly implicated in postpartum psychiatric phenotypes, altered mechanosensory processes may contribute towards depression susceptibility (Howard et al. 2018), and the genomic region around STOML3 has been associated with autism spectrum disorders, psychotic depression, and schizophrenia risk (Domschke 2013; Li et al. 2016; Roberson-Nay et al. 2018; Bitar et al. 2019). A third gene significantly upregulated in the brain of the STS-inhibited mouse model is Arhgdig, encoding the Rho GDP Dissociation Inhibitor Gamma (RhoGDI $\gamma$ ) protein (Humby et al. 2016); the human orthologue of this gene is predominantly expressed in the central nervous system (GTEx Portal 2020) where its protein modulates sensory processes (Ueyama 2019).

Pathway analysis examining less highly differentially expressed genes in the STS-inhibition mouse model $(<1.5$ fold, $p<0.05$ ) suggested that the expression of genes involved in olfactory signalling were disproportionately affected by the pharmacological manipulation (Humby and Davies 2019); this observation is consistent with a role for steroid sulfates as ligands in the mouse accessory olfactory system (Meeks et al. 2010). In humans, olfactory receptors are expressed in the brain with possible enrichment in certain regions (Flegel et al. 2013) and act as G protein-coupled receptors facilitating the influx of calcium/sodium ions via opening of cyclic nucleotide-gated channels (Nowycky and Thomas 2002; Matthews and Reisert 2003). Whilst heterozygous STS deletion has no apparent effect on gross olfactory function (Cavenagh et al. 2019), a more subtle effect cannot be discounted, particularly given that STS inhibition is associated with taste disturbance in female subjects (Stanway et al. 2006).

As the olfactory system and limbic regions extensively connected to it are known to play an important role in mammalian maternal behaviour (Corona and Lévy 2015; Croy et al. 2019), it is plausible that STS deficiency acts to elicit postpartum behavioural symptoms in humans and mice via disturbed olfactory receptor function; potentially, disturbed olfaction could adversely impact upon intermediate phenotypes such as mother-offspring bonding, social judgement, sensory anhedonia, and/or stress modulation. Feasibly, abnormal olfactory processing and the abnormal activity of underlying neural and molecular substrates may play a role in idiopathic postpartum mood disorder risk; consistent with this idea, aberrant olfactory function has been described in several non-postpartum mood conditions (Kamath et al. 2018).

\section{Disrupted expression and function of Communication Cellular Network factor proteins}

The pattern of behavioural effects seen in STS-inhibited postpartum mice signposted a small underlying genetic locus on mouse chromosome 15; brain expression screening of the 17 genes in this interval revealed differential expression (upregulation) of just one, Ccn3 (encoding Cellular Communication Network Factor 3, previously known as Nephroblastoma-overexpressed or NOV) (Humby et al. 2016). CCN3 can form heterodimers with a second communication cellular network (CCN) protein, CCN2 (previously known as CTGF), and there is some evidence that these two proteins exert antagonistic effects (Davies 2019); Ccn2 expression is also upregulated in the STS-inhibited postpartum mouse brain (Humby et al. 2016). CCN2 and CCN3 proteins 
are expressed throughout the cell, but are largely secreted and appear to play an important role in the extracellular matrix (ECM) and multiple associated biological processes including cell proliferation, migration, adhesion, and angiogenesis. CCN2 and CCN3 proteins respond oppositely to mechanical stress in a putative adenylate cyclasemediated process (Schild and Trueb 2004), and, consistent with this, altered adenylate cyclase type 8 (Adcy8) expression is also observed in the STS-inhibited mouse (Humby et al. 2016). CCN proteins are also thought to affect calcium signalling via activation of $G$ proteincoupled receptors, binding to integrins, voltage-gated calcium channels, and/or interaction with intracellular calcium-binding proteins (Lombet et al. 2003). Altered composition or turnover of the ECM has been linked to mood disorders (Lubbers et al. 2014).

Multiple lines of evidence from animal models and clinical studies, summarised previously in Davies (2019), suggest that the $\mathrm{CCN} 2$ and $\mathrm{CCN} 3$ proteins might be considered as interesting candidate mediators of postpartum mood phenotypes. First, their brain expression is altered in three independent animal models exhibiting postpartum behavioural disturbance, including the STS-inhibition mouse model and the porcine 'infanticide' model referred to above (Landers 2019). Second, the CCN3 gene lies directly under a linkage peak identified in a sample of individuals with bipolar affective postpartum psychosis. Third, these genes/proteins are highly expressed in limbic regions of the mammalian brain, show fluctuations in levels through pregnancy and into the postpartum, have been reported to be disrupted in psychotic mood disorders, and mediate relevant behavioural processes including depressive, anxiety-related and neuroticism traits, and sleep. Fourth, of relevance to the idea that precipitous postpartum drops in oestrogen levels stimulate mood changes in some sensitive individuals, oestrogen depletion induces altered $\mathrm{CCN} 3$ expression in rat hippocampus, and $\mathrm{CCN} 2$ physically associates with the oestrogen receptor to affect its function (Cheng et al. 2011); CCN gene expression is also affected by therapeutic drugs such as antipsychotics and mood stabilisers, and by a range of inflammatory mediators including cytokines, prostaglandins, nitric oxide, histamine, and serotonin. Fifth, altered $\mathrm{CCN} 3$ secretion as a consequence of abnormal levels of circulating immunosuppressive regulatory $\mathrm{T}$ cells may provide a link between the perturbed inflammatory processes and brain white matter changes linked to postpartum mood (Krause et al. 2014; Duan et al. 2017; Silver et al. 2018; Dazzan et al. 2018). Finally, CCN3 levels are robustly associated with hypertension, and both $\mathrm{CCN} 2$ and CCN3 proteins have been strongly implicated in the pathogenesis of pre-eclampsia; hence, their abnormal expression may have pleiotropic effects on behavioural and physiological functions and may partially explain the observed link between postpartum mood disorders and pre-eclampsia.
Altered balance between sulfated and free steroid hormones

Potentially, an imbalance between sulfated and free steroids in the postpartum period, and the resultant effects on levels of oestrogens and androgens, could explain the STS deficiency effects on behaviour and physiology described above, and might also play a role in idiopathic postpartum mood disorders. Sulfated steroids are produced and secreted in large quantities by the adrenal glands, and dehydroepiandrosterone sulfate (DHEAS) is the most abundant circulating steroid hormone in humans (Neunzig and Bernhardt 2014). Circulating sulfated steroids are rapidly desulfated by STS upon being transported across the blood-brain barrier via organic anion transporter proteins (OATPs) (Grube et al. 2018).

Allopregnanolone (known by the generic drug name brexanolone when produced synthetically), the levels of which are depleted in the postpartum period, and whose restoration in individuals with postpartum depression appears to confer some therapeutic benefit, is metabolised from its sulfate ester by STS, with the former compound exerting effects at GABAergic and NMDA receptors, and on sodium and calcium channels (Johansson and Le Grevès 2005; Viero and Dayanithi 2008; Li et al. 2010; Horishita et al. 2018). Reductions in STS activity will both lower the availability of allopregnanolone and increase the allopregnanolone sulfate to allopregnanolone ratio with consequent effects on neurotransmitter receptor modulation. Levels of a second neuroactive steroid, pregnenolone, have been positively correlated with postpartum anxiety symptoms (Deligiannidis et al. 2016). Like allopregnanolone, pregnenolone also exists in a sulfated form, which exhibits well-characterised activity at the NMDA receptor (Hrcka Krausova et al. 2020); the ratio of pregnenolone sulfate to pregnenolone is, as expected, higher in individuals with STS deficiency (Sánchez-Guijo et al. 2016). Thus, potentially lower absolute pregnenolone levels, or an elevated pregnenolone sulfate to pregnenolone ratio in STS-deficient individuals, may explain changes in anxiety-related behaviours. In addition to effects at the NMDA receptor, pregnenolone sulfate (in contrast to free pregnenolone) potently activates the Transient Receptor Potential Melastatin 3 (TRPM3) calcium ion channel (Wagner et al. 2008), a molecule expressed in adult human brain (GTEx Portal 2020) and recently implicated in neurodevelopmental/neurological conditions (Zhao et al. 2020). Interestingly, genetic variants within the TRPM3 gene have been associated with abnormal postpartum behaviour in the porcine infanticide model (Bauer 2019) and hippocampal Trpm 3 expression is altered in a mouse model with serotonergic abnormalities and with possible relevance for bipolar disorder (Maddaloni et al. 2018). Functionally, TRPM3 acts as a thermosensitive nociceptor channel implicated in the detection of noxious heat in somatosensory neurons (Thiel et al. 2017); like STOML3, the 
membrane-linked activity of TRPM3 may be affected by binding to cholesterol (Conrard and Tyteca 2019), and its activity also appears to be sensitive to antidepressant and antipsychotic drugs (Majeed et al. 2008).

\section{Conclusions and future research avenues}

The data from STS-deficient systems discussed above, and summarised in Table 1, provide novel clues as to systems and molecules whose function may be disrupted in postpartum mood disorders. An important question is whether there is any central theme to how these molecules might act; the identification and characterisation of such a nexus might allow targeting by therapeutic drugs.

The main theme that emerges is that postpartum mood risk may be a culmination of aberrant steroid hormone modulation of the relationship between extracellular matrix components and membrane receptors involved in perception of the local microenvironment (olfactory, mechanical, $\mathrm{pH}$, and thermal cues) and altered neuronal calcium influx and signalling processes (Fig. 1); consistent with this idea, the gene encoding hemicentin 1 (also known as fibulin-6), an extracellular matrix protein with possible CCN3 binding activity (Vallacchi and Rodolfo 2009) and transmembrane receptor and calcium ion binding activity, has previously been implicated in postpartum mood disorder pathogenesis (Mahon et al. 2009). Brain regions, and their reciprocal connections, of particular interest suggested by the STS work include the olfactory system, the anterior pituitary gland, the lentiform nucleus of the striatum, and the hippocampus; these regions have previously been implicated in postpartum behavioural phenotypes by neuroimaging and histological studies in humans and animal models (Cárdenas et al. 2019; Medina and Workman 2020). Intracellular regulators of calcium influx at cyclic nucleotide-gated channels, e.g. adenylate cyclase and phosphodiesterases (Lane Brown et al. 2006), may also be involved in the pathogenesis of postpartum mood disorders. Abnormal calcium signalling, phosphodiesterase activity, and cyclic AMP/GMP signalling have been implicated in a variety of neurological and psychiatric (mood) conditions (Hebb and Robertson 2007; Harrison et al. 2019), with much focus on phosphodiesterase 10A (PDE10A). PDE10A is highly expressed in the GABAergic neurons of the olfactory tubercle and the striatum (MacMullen et al. 2017), is dysregulated in an animal model of postpartum depression (Yun et al. 2019), and has been genetically associated with bipolar disorder, hypo- and hyperthyroidism, and blood pressure (GWAS Catalog 2020). Although (steroid hormone-dependent) ECM remodelling and calcium signalling have not yet been strongly implicated in postpartum behavioural phenotypes in humans, brain gene expression data in mice have suggested that '..signalling, either through the extracellular matrix or transmembrane receptors, is important during pregnancy, parturition, and the postpartum period' (Ray et al. 2015). Additionally, compared to non-postpartum mice, lactating female mice show gene expression changes in the gonadotropes of the anterior pituitary gland in pathways relating to metal ion transport, cell adhesion, and positive regulation of cGMP metabolic processes (Qiao et al. 2016). Finally, these physiological

Table 1 Phenotypes of STS-deficient individuals and associated biological mechanisms

\begin{tabular}{|c|c|c|}
\hline Experimental group & Associated phenotypes & Possible underlying biological mechanism(s) \\
\hline $\begin{array}{l}\text { Women heterozygous for genetic } \\
\text { deletions including STS }\end{array}$ & $\begin{array}{l}\text { Increased risk of developmental and } \\
\text { (postpartum) mood disorders } \\
\text { Increased self-reported irritability, } \\
\text { psychological distress, manic symptoms, } \\
\text { and tiredness/low energy } \\
\text { Altered sleeping patterns/weight change } \\
\text { Rare cases with paranoid schizophrenia }\end{array}$ & $\begin{array}{l}\text { Decreased volume of basal ganglia structures (putamen, globus } \\
\text { pallidum, nucleus accumbens) }\end{array}$ \\
\hline \multirow[t]{2}{*}{$\begin{array}{l}\text { Male mice with genetic deletions } \\
\text { including Sts, or with STS enzyme } \\
\text { acutely inhibited }\end{array}$} & Inattention & $\begin{array}{l}\text { Increased serotonin (5-HT) levels in the striatum and } \\
\text { hippocampus; increased Htr } 2 c \text { (serotonin 5-HT 2c receptor) } \\
\text { expression in the hippocampus }\end{array}$ \\
\hline & $\begin{array}{l}\text { Increased levels of anxiety-like behaviour, } \\
\text { aggression, and perseveration } \\
\text { Effects on learning and memory } \\
\text { Enhanced response inhibition }\end{array}$ & $\begin{array}{l}\text { Increased hippocampal acetylcholine release } \\
\text { Imbalance between sulfated and free steroids (notably increased } \\
\text { dehydroepiandrosterone sulfate (DHEAS) and decreased } \\
\text { DHEA) }\end{array}$ \\
\hline $\begin{array}{l}\text { Postpartum female mice with STS } \\
\text { enzyme acutely inhibited }\end{array}$ & $\begin{array}{l}\text { Decreased acoustic startle response; } \\
\text { alleviated by antipsychotic administration } \\
\text { Altered exploration of aversive environment }\end{array}$ & $\begin{array}{l}\text { Increased whole-brain expression of } C c n 2, C c n 3, A d c y 8, \\
\text { Arhgdig, Cyp } 2 g 1, \text { Stoml } 3 \text {, and genes involved in olfactory } \\
\text { signalling }\end{array}$ \\
\hline Postpartum female pigs & $\begin{array}{l}\text { Infanticidal behaviour together with } \\
\text { anxiety/restlessness in }<10 \% \text { individuals }\end{array}$ & $\begin{array}{l}\text { Quantitative trait loci overlapping Sts and } H t r 2 c \text {; increased Ccn } 2 \\
\text { and } H t r 2 c \text { (long variant) expression in the hypothalamus/brain }\end{array}$ \\
\hline
\end{tabular}




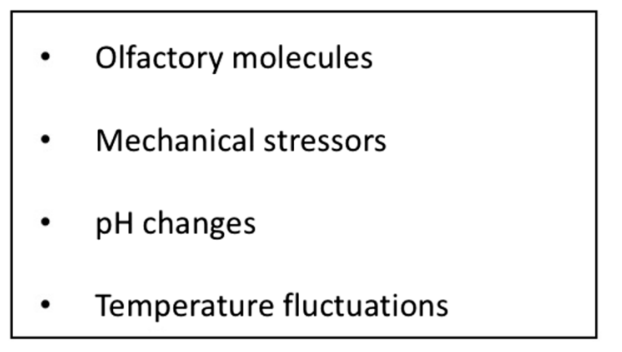

\section{ENVIRONMENTAL AND HORMONAL CUES}
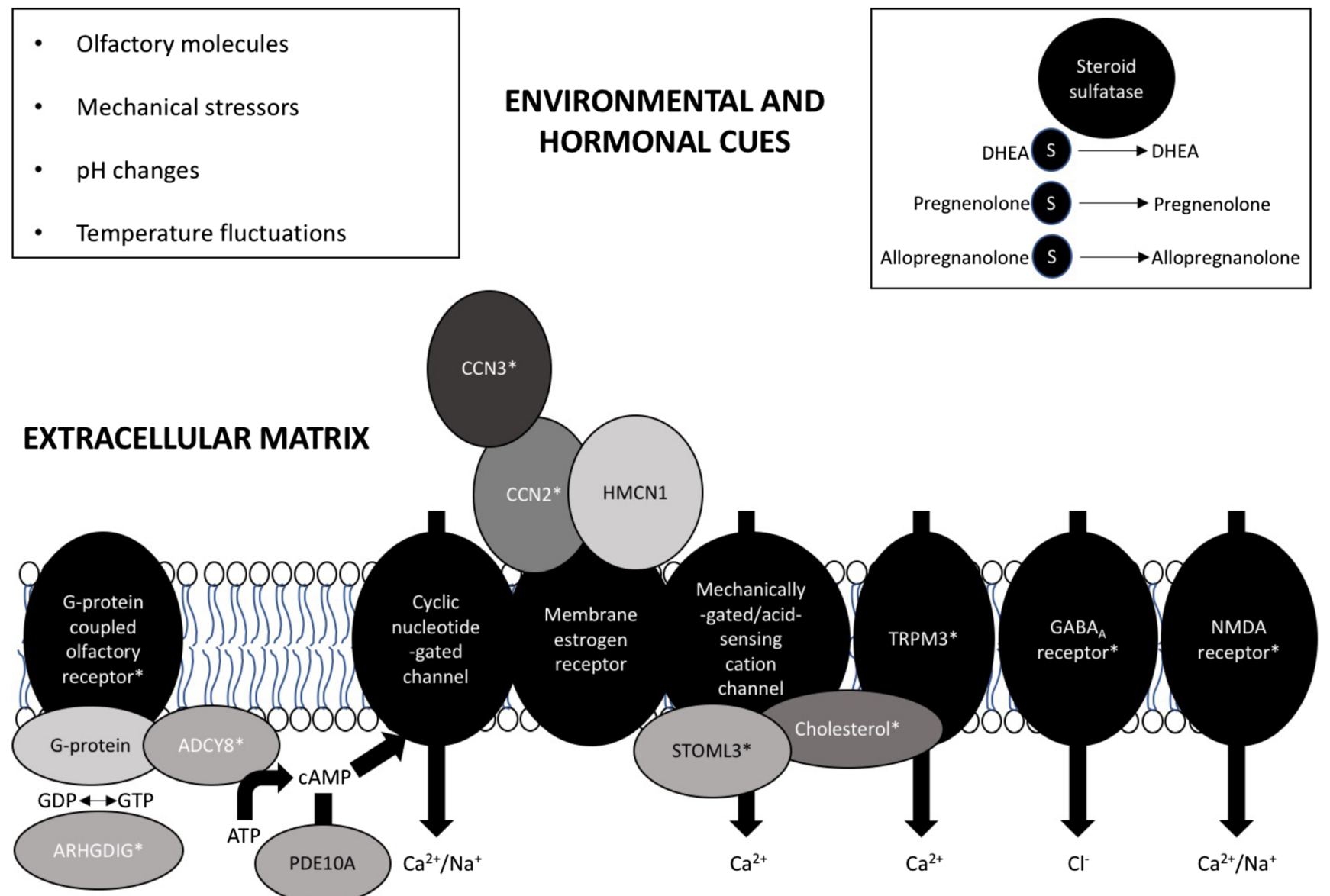

INTRACELLULAR

Fig. 1 External environmental cues can stimulate neuronal calcium $\left(\mathrm{Ca}^{2+}\right)$ influx via effects on extracellular matrix components (notably $\mathrm{CCN}$ proteins and hemicentin (HMCN1)), a variety of transmembrane receptors, and intracellular signalling cascades; the expression/activity of

processes are known to play a prominent role in extra-brain peripartum events including lactation (Cross et al. 2014; Davis 2017), uterine contractions (Loftus et al. 2015), immune system activation (Kimura et al. 2006), and structural changes in the mammary gland, uterus, and ovaries (Thorne et al. 2015).

The ideas discussed above suggest a number of interrelated predictions. Specifically, compared to healthy controls, individuals with idiopathic postpartum mood disorders and relevant animal models may display (a) an elevated ratio of sulfated to free circulating steroids including allopregnanolone, pregnenolone, and cholesterol; (b) genetic association with, and altered expression/activity of, steroidmodulating, extracellular matrix, and signalling molecules (e.g. STS, STOML3, CCN2, CCN3, ADCY8, ARHGDIG, HMCN1, TRPM3, and PDE10A); and (c) evidence for dysregulation of calcium signalling. If any of these predictions are confirmed, the results may inform development of predictive biomarkers and should stimulate further work into identifying specific cellular and molecular risk pathways. Potentially, many of these proteins is differentially sensitive to sulfated and free steroids, and/or is affected by steroid sulfatase (STS) deficiency (indicated with an asterisk symbol)

therapies addressing steroid hormone-dependent perturbations, notably dysfunctional calcium signalling, may be beneficial in treating postpartum mood disorders.

Code availability Not applicable

Data availability Not applicable

\section{Compliance with ethical standards}

Conflict of interest The authors declare that they have no conflict of interest.

Ethical approval Not applicable

Consent to participate Not applicable

Consent for publication The authors consent to publication of this manuscript.

Research involving human participants and/or animals Not applicable 
Open Access This article is licensed under a Creative Commons Attribution 4.0 International License, which permits use, sharing, adaptation, distribution and reproduction in any medium or format, as long as you give appropriate credit to the original author(s) and the source, provide a link to the Creative Commons licence, and indicate if changes were made. The images or other third party material in this article are included in the article's Creative Commons licence, unless indicated otherwise in a credit line to the material. If material is not included in the article's Creative Commons licence and your intended use is not permitted by statutory regulation or exceeds the permitted use, you will need to obtain permission directly from the copyright holder. To view a copy of this licence, visit http://creativecommons.org/licenses/by/4.0/.

\section{References}

Babalola PA, Fitz NF, Gibbs RB, Flaherty PT, Li PK, Johnson DA (2012) The effect of the steroid sulfatase inhibitor (p-O-sulfamoyl)-tetradecanoyl tyramine (DU-14) on learning and memory in rats with selective lesion of septal-hippocampal cholinergic tract. Neurobiol Learn Mem 98:303-310. https://doi.org/10.1016/j.nlm. 2012.09.003

Bauer J (2019) Investigation of the genetic components of maternal infanticide in Sus scrofa. Ph.D thesis, University of Cambridge. https://doi.org/10.17863/CAM.40257

Bergink V, Kushner SA, Pop V, Kuijpens H, Lambregtse-van den Berg MP, Drexhage RC, Wiersinga W, Nolen WA, Drexhage HA (2011) Prevalence of autoimmune thyroid dysfunction in postpartum psychosis. Br J Psychiatry 198:264-268. https://doi.org/10.1192/bjp. bp. 110.082990

Bergink V, Burgerhout KM, Weigelt K, Pop VJ, de Wit H, Drexhage RC, Kushner SA, Drexhage HA (2013) Immune system dysregulation in first-onset postpartum psychosis. Biol Psychiatry 73:1000-1007. https://doi.org/10.1016/j.biopsych.2012.11.006

Bergink V, Laursen TM, Johannsen BMW et al (2015) Pre-eclampsia and first-onset postpartum psychiatric episodes: a Danish populationbased cohort study. Psychol Med 45:1-9. https://doi.org/10.1017/ S0033291715001385

Bergink V, Rasgon N, Wisner KL (2016) Postpartum psychosis: madness, mania, and melancholia in motherhood. Am J Psychiatry 173: 1179-1188. https://doi.org/10.1176/appi.ajp.2016.16040454

Bitar T, Hleihel W, Marouillat S, Vonwill S, Vuillaume ML, Soufia M, Vourc'h P, Laumonnier F, Andres CR (2019) Identification of rare copy number variations reveals PJA2, APCS, SYNPO, and TAC1 as novel candidate genes in autism spectrum disorders. Mol Genet Genomic Med 7:e786. https://doi.org/10.1002/mgg3.786

Blackmore ER, Rubinow DR, O'Connor TG et al (2013) Reproductive outcomes and risk of subsequent illness in women diagnosed with postpartum psychosis. Bipolar Disord 15:394-404. https://doi.org/ 10.1111/bdi. 12071

Bouman A, Jan Heineman M, MFaas M (2005) Sex hormones and the immune response in humans. Hum Reprod Update 11:411-423. https://doi.org/10.1093/humupd/dmi008

Brcic L, Underwood JFG, Kendall KM, Caseras X, Kirov G, Davies W (2020) Medical and neurobehavioural phenotypes in carriers of Xlinked ichthyosis-associated genetic deletions in the UK Biobank. J Med Genet 57:692-698. https://doi.org/10.1136/jmedgenet-2019106676

Cárdenas EF, Kujawa A, Humphreys KL (2019) Neurobiological changes during the peripartum period: implications for health and behavior. Soc Cogn Affect Neurosci 15:1-14. https://doi.org/10.1093/scan/nsz091

Caropreso L, de Azevedo CT, Eltayebani M, Frey BN (2019) Preeclampsia as a risk factor for postpartum depression and psychosis: a systematic review and meta-analysis. Arch Womens Ment Health 23:493-505. https://doi.org/10.1007/s00737-01901010-1

Cavenagh A, Chatterjee S, Davies W (2019) Behavioural and psychiatric phenotypes in female carriers of genetic mutations associated with X-linked ichthyosis. PLoS One 14:e0212330. https://doi.org/10. 1371/journal.pone. 0212330

Cheng L, Yang Z, Wang X, Jiao Y, Xie X, Lin J, Zhang H, Han J, Jiang K, Ye Q (2011) Suppression of estrogen receptor transcriptional activity by connective tissue growth factor. PLoS One 6:e20028. https://doi.org/10.1371/journal.pone.0020028

Conrard L, Tyteca D (2019) Regulation of membrane calcium transport proteins by the surrounding lipid environment. Biomolecules 9:513. https://doi.org/10.3390/biom9100513

Corona R, Lévy F (2015) Chemical olfactory signals and parenthood in mammals. Horm Behav 68:77-90. https://doi.org/10.1016/j.yhbeh. 2014.06.018

Cross BM, Breitwieser GE, Reinhardt TA, Rao R (2014) Cellular calcium dynamics in lactation and breast cancer: from physiology to pathology. Am J Phys Cell Phys 306:c515-c526. https://doi.org/10.1152/ ajpcell.00330.2013

Croy I, Mohr T, Weidner K, Hummel T, Junge-Hoffmeister J (2019) Mother-child bonding is associated with the maternal perception of the child's body odour. Physiol Behav 198:151-157. https://doi. org/10.1016/j.physbeh.2018.09.014

Davies W (2012) Does steroid sulfatase deficiency influence postpartum psychosis risk? Trends Mol Med 18:256-262. https://doi.org/10. 1016/j.molmed.2012.03.001

Davies W (2018) The steroid sulfate axis and its relationship to maternal behaviour and mental health. J Mol Endocrinol 61:T199-T210. https://doi.org/10.1530/JME-17-0219

Davies W (2019) An analysis of cellular communication network factor proteins as candidate mediators of postpartum psychosis risk. Front Psychiatr 10. https://doi.org/10.3389/fpsyt.2019.00876

Davies W, Humby T, Kong W, Otter T, Burgoyne PS, Wilkinson LS (2009) Converging pharmacological and genetic evidence indicates a role for steroid sulfatase in attention. Biol Psychiatry 66:360-367. https://doi.org/10.1016/j.biopsych.2009.01.001

Davies W, Humby T, Trent S, Eddy JB, Ojarikre OA, Wilkinson LS (2014) Genetic and pharmacological modulation of the steroid sulfatase axis improves response control; comparison with drugs used in ADHD. Neuropsychopharmacology 39:2622-2632. https://doi. org/10.1038/npp.2014.115

Davis FM (2017) The ins and outs of calcium signalling in lactation and involution: implications for breast cancer treatment. Pharmacol Res 116:100-104. https://doi.org/10.1016/j.phrs.2016.12.007

Dazzan P, Fusté M, Davies W (2018) Do defective immune systemmediated myelination processes increase postpartum psychosis risk? Trends Mol Med 24:942-949. https://doi.org/10.1016/j.molmed. 2018.09.002

Deligiannidis KM, Kroll-Desrosiers AR, Mo S, Nguyen HP, Svenson A, Jaitly N, Hall JE, Barton BA, Rothschild AJ, Shaffer SA (2016) Peripartum neuroactive steroid and $\gamma$-aminobutyric acid profiles in women at-risk for postpartum depression. Psychoneuroendocrinology 70:98-107. https://doi.org/10.1016/j. psyneuen.2016.05.010

Di Florio A, Gordon-Smith K, Forty L et al (2018) Stratification of the risk of bipolar disorder recurrences in pregnancy and postpartum. $\mathrm{Br}$ J Psychiatry 213:542-547. https://doi.org/10.1192/bjp.2018.92

Domschke K (2013) Clinical and molecular genetics of psychotic depression. Schizophr Bull 39:766-775. https://doi.org/10.1093/schbul/ sbt040

Duan C, Cosgrove J, Deligiannidis KM (2017) Understanding peripartum depression through neuroimaging: a review of structural and functional connectivity and molecular imaging research. Curr Psychiatr Rep 19:70. https://doi.org/10.1007/s11920-017-0824-4 
Fawcett EJ, Fairbrother N, Cox ML, White IR, Fawcett JM (2019) The prevalence of anxiety disorders during pregnancy and the postpartum period: a multivariate Bayesian meta-analysis. J Clin Psychiatry 80. https://doi.org/10.4088/JCP.18r12527

Flegel C, Manteniotis S, Osthold S, Hatt H, Gisselmann G (2013) Expression profile of ectopic olfactory receptors determined by deep sequencing. PLoS One 8. https://doi.org/10.1371/journal.pone. 0055368

Geyer J, Bakhaus K, Bernhardt R, Blaschka C, Dezhkam Y, Fietz D, Grosser G, Hartmann K, Hartmann MF, Neunzig J, Papadopoulos D, Sánchez-Guijo A, Scheiner-Bobis G, Schuler G, Shihan M, Wrenzycki C, Wudy SA, Bergmann M (2017) The role of sulfated steroid hormones in reproductive processes. J Steroid Biochem Mol Biol 172:207-221. https://doi.org/10.1016/j.jsbmb.2016.07.002

Grube M, Hagen P, Jedlitschky G (2018) Neurosteroid transport in the brain: role of ABC and SLC transporters. Front Pharmacol 9. https:// doi.org/10.3389/fphar.2018.00354

GTEx Portal (2020) https://www.gtexportal.org/home/ Accessed $15^{\text {th }}$ July 2020

Guintivano J, Manuck T, Meltzer-Brody S (2018) Predictors of postpartum depression: a comprehensive review of the last decade of evidence. Clin Obstet Gynecol 61:591-603. https://doi.org/10.1097/ GRF.0000000000000368

GWAS Catalog (2020) https://www.ebi.ac.uk/gwas/ Accessed $15^{\text {th }}$ July 2020

Harrison PJ, Hall N, Mould A, al-Juffali N, Tunbridge EM (2019) Cellular calcium in bipolar disorder: systematic review and metaanalysis. Mol Psychiatry. https://doi.org/10.1038/s41380-019-0622$\mathrm{y}$

Hebb ALO, Robertson HA (2007) Role of phosphodiesterases in neurological and psychiatric disease. Curr Opin Pharmacol 7:86-92. https://doi.org/10.1016/j.coph.2006.08.014

Horishita T, Yanagihara N, Ueno S, Okura D, Horishita R, Minami T, Ogata Y, Sudo Y, Uezono Y, Kawasaki T (2018) The neurosteroid allopregnanolone sulfate inhibits Nav1.3 $\alpha$ subunit-containing voltage-gated sodium channels, expressed in Xenopus oocytes. J Pharmacol Sci 137:93-97. https://doi.org/10.1016/j.jphs.2018.01. 010

Howard DM, Adams MJ, Shirali M et al (2018) Genome-wide association study of depression phenotypes in UK Biobank identifies variants in excitatory synaptic pathways. Nat Commun 9:1470. https:// doi.org/10.1038/s41467-018-03819-3

Hrcka Krausova B, Kysilov B, Cerny J, Vyklicky V, Smejkalova T, Ladislav M, Balik A, Korinek M, Chodounska H, Kudova E, Vyklicky L (2020) Site of action of brain neurosteroid pregnenolone sulfate at the N-methyl-D-aspartate receptor. J Neurosci 40:59225936. https://doi.org/10.1523/JNEUROSCI.3010-19.2020

Humby T, Davies W (2019) Brain gene expression in a novel mouse model of postpartum mood disorder. Transl Neurosci 10:168-174. https://doi.org/10.1515/tnsci-2019-0030

Humby T, Cross ES, Messer L, Guerrero S, Davies W (2016) A pharmacological mouse model suggests a novel risk pathway for postpartum psychosis. Psychoneuroendocrinology 74:363-370. https://doi. org/10.1016/j.psyneuen.2016.09.019

Johansson T, Le Grevès P (2005) The effect of dehydroepiandrosterone sulfate and allopregnanolone sulfate on the binding of [(3)H]ifenprodil to the N-methyl-d-aspartate receptor in rat frontal cortex membrane. J Steroid Biochem Mol Biol 94:263-266. https:// doi.org/10.1016/j.jsbmb.2005.01.020

Johnson DA, Wu TH, Li PK, Maher TJ (2000) The effect of steroid sulfatase inhibition on learning and spatial memory. Brain Res 865:286-290. https://doi.org/10.1016/S0006-8993(00)02372-6

Kamath V, Lasutschinkow P, Ishizuka K, Sawa A (2018) Olfactory functioning in first-episode psychosis. Schizophr Bull 44:672-680. https://doi.org/10.1093/schbul/sbx107
Kimura K, Reinhardt TA, Goff JP (2006) Parturition and hypocalcemia blunts calcium signals in immune cells of dairy cattle. J Dairy Sci 89:2588-2595. https://doi.org/10.3168/jds.S0022-0302(06)723359

Krause D, Jobst A, Kirchberg F, Kieper S, Härtl K, Kästner R, Myint AM, Müller N, Schwarz MJ (2014) Prenatal immunologic predictors of postpartum depressive symptoms: a prospective study for potential diagnostic markers. Eur Arch Psychiatry Clin Neurosci 264:615-624. https://doi.org/10.1007/s00406-014-0494-8

Kumar MM, Venkataswamy MM, Sathyanarayanan G, Thippeswamy H, Chandra PS, Mani RS (2017) Immune system aberrations in postpartum psychosis: an immunophenotyping study from a tertiary care neuropsychiatric hospital in India. J Neuroimmunol 310:8-13. https://doi.org/10.1016/j.jneuroim.2017.06.002

Landers CA (2019) Using a porcine maternal infanticide model to investigate the inheritance of human puerperal psychosis. Ph.D thesis, University of Cambridge. https://doi.org/10.17863/CAM.31731

Lane Brown R, Strassmaier T, Brady J, Karpen J (2006) The pharmacology of cyclic nucleotide-gated channels: emerging from the darkness. Curr Pharm Des 12:3597-3613. https://doi.org/10.2174/ 138161206778522100

Lewis KJS, Di Florio A, Forty L et al (2018) Mania triggered by sleep loss and risk of postpartum psychosis in women with bipolar disorder. J Affect Disord 225:624-629. https://doi.org/10.1016/j.jad. 2017.08.054

Li P, Khatri A, Bracamontes J, Weiss DS, Steinbach JH, Akk G (2010) Site-specific fluorescence reveals distinct structural changes induced in the human $\rho 1$ GABA receptor by inhibitory neurosteroids. Mol Pharmacol 77:539-546. https://doi.org/10.1124/mol.109.062885

Li Z, Chen J, Xu Y, Yi Q, Ji W, Wang P, Shen J, Song Z, Wang M, Yang P, Wang Q, Feng G, Liu B, Sun W, Xu Q, Li B, He L, He G, Li W, Wen Z, Liu K, Huang F, Zhou J, Ji J, Li X, Shi Y (2016) Genomewide analysis of the role of copy number variation in schizophrenia risk in Chinese. Biol Psychiatry 80:331-337. https://doi.org/10. 1016/j.biopsych.2015.11.012

Loftus FC, Richardson MJE, Shmygol A (2015) Single-cell mechanics and calcium signalling in organotypic slices of human myometrium. J Biomech 48:1620-1624. https://doi.org/10.1016/j.jbiomech.2015. 01.046

Lombet A, Planque N, Bleau AM, Li CL, Perbal B (2003) CCN3 and calcium signaling. Cell Commun Signal 1:1. https://doi.org/10 1186/1478-811X-1-1

Lubbers BR, Smit AB, Spijker S, van den Oever MC (2014) Neural ECM in addiction, schizophrenia, and mood disorder. Prog Brain Res 214: 263-284. https://doi.org/10.1016/B978-0-444-63486-3.00012-8

Lusskin SI, Khan SJ, Ernst C et al (2018) Pharmacotherapy for perinatal depression. Clin Obstet Gynecol 61:544-561. https://doi.org/10. 1097/GRF.0000000000000365

Lykkesfeldt G, Lykkesfeldt AE, Skakkebaek NE (1984) Steroid sulphatase in man: a non inactivated X-locus with partial gene dosage compensation. Hum Genet 65:355-357. https://doi.org/10. 1007/BF00291559

MacMullen CM, Fallahi M, Davis RL (2017) Novel PDE10A transcript diversity in the human striatum: insights into gene complexity, conservation and regulation. Gene 606:17-24. https://doi.org/10.1016/j. gene.2016.12.033

Maddaloni G, Migliarini S, Napolitano F, Giorgi A, Nazzi S, Biasci D, de Felice A, Gritti M, Cavaccini A, Galbusera A, Franceschi S, Lessi F, Ferla ML, Aretini P, Mazzanti CM, Tonini R, Gozzi A, Usiello A, Pasqualetti M (2018) Serotonin depletion causes valproateresponsive manic-like condition and increased hippocampal neuroplasticity that are reversed by stress. Sci Rep 8:11847. https://doi.org/10.1038/s41598-018-30291-2

Mahon PB, Payne JL, MacKinnon DF et al (2009) Genome-wide linkage and follow-up association study of postpartum mood symptoms. 
Am J Psychiatry 166:1229-1237. https://doi.org/10.1176/appi.ajp. 2009.09030417

Majeed Y, Naylor J, Zeng F et al (2008) Inhibition of TRPM3 channel by anti-depressant and anti-psychotic drugs. FASEB J. https://doi.org/ 10.1096/FASEBJ.22.1 SUPPLEMENT.937.5

Martin RD (2007) The evolution of human reproduction: a primatological perspective. Am J Phys Anthropol Suppl 45:59-84. https://doi.org/ 10.1002/ajpa.20734

Matthews HR, Reisert J (2003) Calcium, the two-faced messenger of olfactory transduction and adaptation. Curr Opin Neurobiol 13: 469-475. https://doi.org/10.1016/S0959-4388(03)00097-7

Medina J, Workman JL (2020) Maternal experience and adult neurogenesis in mammals: implications for maternal care, cognition, and mental health. J Neurosci Res 98:1293-1308. https://doi.org/10. 1002/jnr.24311

Meeks JP, Arnson HA, Holy TE (2010) Representation and transformation of sensory information in the mouse accessory olfactory system. Nat Neurosci 13:723-730. https://doi.org/10.1038/nn.2546

Meltzer-Brody S, Colquhoun H, Riesenberg R, Epperson CN, Deligiannidis KM, Rubinow DR, Li H, Sankoh AJ, Clemson C, Schacterle A, Jonas J, Kanes S (2018a) Brexanolone injection in post-partum depression: two multicentre, double-blind, randomised, placebo-controlled, phase 3 trials. Lancet 392:1058-1070. https:// doi.org/10.1016/S0140-6736(18)31551-4

Meltzer-Brody S, Howard LM, Bergink V, Vigod S, Jones I, MunkOlsen T, Honikman S, Milgrom J (2018b) Postpartum psychiatric disorders. Nat Rev Dis Prim 4:18022. https://doi.org/10.1038/nrdp. 2018.22

Milunsky J, Huang XL, Wyandt HE, Milunsky A (1999) Schizophrenia susceptibility gene locus at Xp22.3. Clin Genet 55:455-460. https:// doi.org/10.1034/j.1399-0004.1999.550610.x

Minaldi E, D'Andrea S, Castellini C, Martorella A, Francavilla F, Francavilla S, Barbonetti A (2020) Thyroid autoimmunity and risk of post-partum depression: a systematic review and meta-analysis of longitudinal studies. J Endocrinol Investig 43:271-277. https://doi. org/10.1007/s40618-019-01120-8

Mueller JW, Gilligan LC, Idkowiak J, Arlt W, Foster PA (2015) The regulation of steroid action by sulfation and desulfation. Endocr Rev 36:526-563. https://doi.org/10.1210/er.2015-1036

Neunzig J, Bernhardt R (2014) Dehydroepiandrosterone sulfate (DHEAS) stimulates the first step in the biosynthesis of steroid hormones. PLoS One 9:89727. https://doi.org/10.1371/journal. pone. 0089727

Nicolas LB, Pinoteau W, Papot S, Routier S, Guillaumet G, Mortaud S (2001) Aggressive behavior induced by the steroid sulfatase inhibitor COUMATE and by DHEAS in CBA/H mice. Brain Res 922: 216-222. https://doi.org/10.1016/S0006-8993(01)03171-7

Nowycky MC, Thomas AP (2002) Intracellular calcium signaling. J Cell Sci 115:3715-3716. https://doi.org/10.1242/jcs.00078

Paul SM, Pinna G, Guidotti A (2020) Allopregnanolone: from molecular pathophysiology to therapeutics. A historical perspective. Neurobiol Stress 12:100215. https://doi.org/10.1016/j.ynstr.2020.100215

Payne JL, Osborne LM, Cox O, Kelly J, Meilman S, Jones I, Grenier W, Clark K, Ross E, McGinn R, Wadhwa PD, Entringer S, Dunlop AL, Knight AK, Smith AK, Buss C, Kaminsky ZA (2020) DNA methylation biomarkers prospectively predict both antenatal and postpartum depression. Psychiatry Res 285:112711. https://doi.org/10. 1016/j.psychres.2019.112711

Perani CV, Slattery DA (2014) Using animal models to study postpartum psychiatric disorders. Br J Pharmacol 171:4539-4555. https://doi.org/10.1111/bph.12640

Poels EMP, Bijma HH, Galbally M, Bergink V (2018) Lithium during pregnancy and after delivery: a review. Int J Bipolar Disord 6:26. https://doi.org/10.1186/s40345-018-0135-7

Qi Y, Andolfi L, Frattini F, Mayer F, Lazzarino M, Hu J (2015) Membrane stiffening by STOML3 facilitates mechanosensation in sensory neurons. Nat Commun 6:8512. https://doi.org/10.1038/ ncomms 9512

Qiao S, Nordström K, Muijs L, Gasparoni G, Tierling S, Krause E, Walter J, Boehm U (2016) Molecular plasticity of male and female murine gonadotropes revealed by mRNA sequencing. Endocrinology 157: 1082-1093. https://doi.org/10.1210/en.2015-1836

Quilter CR, Blott SC, Wilson AE et al (2007) Porcine maternal infanticide as a model for puerperal psychosis. Am J Med Genet Part B Neuropsychiatr Genet 144:862-868. https://doi.org/10.1002/ajmg. b.30529

Ray S, Tzeng RY, DiCarlo LM et al (2015) An examination of dynamic gene expression changes in the mouse brain during pregnancy and the postpartum period. G3 6:221-233. https://doi.org/10.1534/g3. 115.020982

Reddy MSS, Thippeswamy H, Ganjekar S, Nagappa M, Mahadevan A, Arvinda HR, Chandra PS, Taly AB (2018) Anti-NMDA receptor encephalitis presenting as postpartum psychosis-a clinical description and review. Arch Womens Ment Health 21:465-469. https:// doi.org/10.1007/s00737-018-0816-3

Reed MJ, Purohit A, Woo LWL, Newman SP, Potter BVL (2005) Steroid sulfatase: molecular biology, regulation, and inhibition. Endocr Rev 26:171-202. https://doi.org/10.1210/er.2004-0003

Rezaie-Keikhaie K, Arbabshastan ME, Rafiemanesh H, Amirshahi M, Ostadkelayeh SM, Arbabisarjou A (2020) Systematic review and meta-analysis of the prevalence of the maternity blues in the postpartum period. J Obstet Gynecol Neonatal Nurs 49:127-136. https:// doi.org/10.1016/j.jogn.2020.01.001

Roberson-Nay R, Wolen AR, Lapato DM, et al (2018) Twin study of early-onset major depression finds DNA methylation enrichment for neurodevelopmental genes bioRxiv 422345. https://doi.org/10. $1101 / 422345$

Sánchez-Guijo A, Neunzig J, Gerber A, Oji V, Hartmann MF, Schuppe HC, Traupe H, Bernhardt R, Wudy SA (2016) Role of steroid sulfatase in steroid homeostasis and characterization of the sulfated steroid pathway: evidence from steroid sulfatase deficiency. Mol Cell Endocrinol 437:142-153. https://doi.org/10.1016/j.mce.2016. 08.019

Schild C, Trueb B (2004) Three members of the connective tissue growth factor family $\mathrm{CCN}$ are differentially regulated by mechanical stress. Biochim Biophys Acta, Mol Cell Res 1691:33-40. https://doi.org/ 10.1016/j.bbamcr.2003.12.001

Sheng J, Guo J, Hua Z, Caggana M, Ding X (2000) Characterization of human CYP2G genes: widespread loss-of-function mutations and genetic polymorphism. Pharmacogenetics 10:667-678. https://doi. org/10.1097/00008571-200011000-00001

Silver M, Moore CM, Villamarin V, Jaitly N, Hall JE, Rothschild AJ, Deligiannidis KM (2018) White matter integrity in medication-free women with peripartum depression: a tract-based spatial statistics study. Neuropsychopharmacology 43:1573-1580. https://doi.org/ 10.1038/s41386-018-0023-y

Stanway SJ, Purohit A, Woo LWL, Sufi S, Vigushin D, Ward R, Wilson RH, Stanczyk FZ, Dobbs N, Kulinskaya E, Elliott M, Potter BV, Reed MJ, Coombes RC (2006) Phase I study of STX 64 (667 Coumate) in breast cancer patients: the first study of a steroid sulfatase inhibitor. Clin Cancer Res 12:1585-1592. https://doi.org/10. 1158/1078-0432.CCR-05-1996

Stergiakouli E, Langley K, Williams H, Walters J, Williams NM, Suren S, Giegling I, Wilkinson LS, Owen MJ, O'Donovan MC, Rujescu D, Thapar A, Davies W (2011) Steroid sulfatase is a potential modifier of cognition in attention deficit hyperactivity disorder. Genes Brain Behav 10:334-344. https://doi.org/10.1111/j.1601-183X. 2010.00672.x

Tagawa N, Hidaka Y, Takano T, Shimaoka Y, Kobayashi Y, Amino N (2004a) Serum concentrations of dehydroepiandrosterone and dehydroepiandrosterone sulfate and their relation to cytokine production 
during and after normal pregnancy. Clin Chim Acta 340:187-193. https://doi.org/10.1016/j.ccen.2003.10.018

Tagawa N, Hidaka Y, Takano T, Shimaoka Y, Kobayashi Y, Amino N (2004b) Serum concentrations of androstenediol and androstenediol sulfate, and their relation to cytokine production during and after normal pregnancy. Steroids 69:675-680. https://doi.org/10.1016/j. steroids.2004.06.003

Thiel G, Rubil S, Lesch A, Guethlein LA, Rössler OG (2017) Transient receptor potential TRPM3 channels: pharmacology, signaling, and biological functions. Pharmacol Res 124:92-99. https://doi.org/10. 1016/j.phrs.2017.07.014

Thorne JT, Segal TR, Chang S, Jorge S, Segars JH, Leppert PC (2015) Dynamic reciprocity between cells and their microenvironment in reproduction. Biol Reprod 92:25. https://doi.org/10.1095/ biolreprod.114.121368

Trent S, Davies W (2013) Cognitive, behavioural and psychiatric phenotypes associated with steroid sulfatase deficiency. World J Transl Med 2:1-12. https://doi.org/10.5528/wjtm.v2.i1.1

Trent S, Cassano T, Bedse G, Ojarikre OA, Humby T, Davies W (2012a) Altered serotonergic function may partially account for behavioral endophenotypes in steroid sulfatase-deficient mice. Neuropsychopharmacology 37:1267-1274. https://doi.org/10. 1038/npp.2011.314

Trent S, Dennehy A, Richardson H, Ojarikre OA, Burgoyne PS, Humby T, Davies W (2012b) Steroid sulfatase-deficient mice exhibit endophenotypes relevant to attention deficit hyperactivity disorder. Psychoneuroendocrinology 37:221-229. https://doi.org/10.1016/j. psyneuen.2011.06.006

Trent S, Dean R, Veit B, Cassano T, Bedse G, Ojarikre OA, Humby T, Davies W (2013) Biological mechanisms associated with increased perseveration and hyperactivity in a genetic mouse model of neurodevelopmental disorder. Psychoneuroendocrinology 38: 1370-1380. https://doi.org/10.1016/j.psyneuen.2012.12.002

Ueyama T (2019) Rho-family small GTPases: from highly polarized sensory neurons to cancer cells. Cells 8:92. https://doi.org/10. $3390 /$ cells 8020092

Vallacchi V, Rodolfo M (2009) Regulatory role of CCN3 in melanoma cell interaction with the extracellular matrix. Cell Adhes Migr 3:710. https://doi.org/10.4161/cam.3.1.6836
VanderKruik R, Barreix M, Chou D et al (2017) The global prevalence of postpartum psychosis: a systematic review. BMC Psychiatr 17:272. https://doi.org/10.1186/s12888-017-1427-7

Viero C, Dayanithi G (2008) Neurosteroids are excitatory in supraoptic neurons but inhibitory in the peripheral nervous system: it is all about oxytocin and progesterone receptors. Prog Brain Res 170: 177-192. https://doi.org/10.1016/S0079-6123(08)00416-0

Wagner TFJ, Loch S, Lambert S, Straub I, Mannebach S, Mathar I, Düfer M, Lis A, Flockerzi V, Philipp SE, Oberwinkler J (2008) Transient receptor potential M3 channels are ionotropic steroid receptors in pancreatic $\beta$ cells. Nat Cell Biol 10:1421-1430. https://doi.org/10. $1038 /$ ncb 1801

Wetzel C, Pifferi S, Picci C, Gök C, Hoffmann D, Bali KK, Lampe A, Lapatsina L, Fleischer R, Smith ESJ, Bégay V, Moroni M, Estebanez L, Kühnemund J, Walcher J, Specker E, Neuenschwander M, von Kries JP, Haucke V, Kuner R, Poulet JFA, Schmoranzer J, Poole K, Lewin GR (2017) Small-molecule inhibition of STOML3 oligomerization reverses pathological mechanical hypersensitivity. Nat Neurosci 20:209-218. https://doi. org/10.1038/nn.4454

Yue XH, Tong JQ, Wang ZJ, Zhang J, Liu X, Liu XJ, Cai HY, Qi JS (2016) Steroid sulfatase inhibitor DU-14 protects spatial memory and synaptic plasticity from disruption by amyloid $\beta$ protein in male rats. Horm Behav 83:83-92. https://doi.org/10.1016/j.yhbeh.2016. 05.019

Yun H, Park ES, Choi S, Shin B, Yu J, Yu J, Amarasekara DS, Kim S, Lee N, Choi JS, Choi Y, Rho J (2019) TDAG51 is a crucial regulator of maternal care and depressive-like behavior after parturition. PLoS Genet 15:e1008214. https://doi.org/10.1371/journal.pgen. 1008214

Zha XM (2013) Acid-sensing ion channels: trafficking and synaptic function. Mol Brain 6:1. https://doi.org/10.1186/1756-6606-6-1

Zhao S, Yudin Y, Rohacs T (2020) Disease-associated mutations in the human TRPM3 render the channel overactive via two distinct mechanisms. Elife. 9. https://doi.org/10.7554/eLife.55634

Publisher's note Springer Nature remains neutral with regard to jurisdictional claims in published maps and institutional affiliations. 